\title{
Part-time or Full-time Employment: Choices and Constraints'
}

\section{Kari Ingstad ${ }^{2}$}

Associate professor, The Faculty of Nursing and Health Sciences, Nord University, Norway

\section{Marianne Hedlund}

Professor, The Faculty of Nursing and Health Sciences, Nord University, Norway

\begin{abstract}
This article explores nurses' working-hour practices in Norwegian nursing homes through a career path. Although the nursing profession is dominated by women and is a typical part-time occupation, this study found variations in working-hour patterns among nurses. These variations suggest that nurses not only have different career patterns but also that the working hours of individual nurses vary throughout a career. The analysis highlights different contextual factors that influence nurses' working hours during their careers. The findings are based on data collected through in-depth interviews with 22 nurses over the age of 56. As a result, we conclude that the working-hour patterns of nurses are constructed out of interactions among the welfare state, the labor market, and family practices, meaning that workinghour patterns can be influenced and changed.
\end{abstract}

\section{KEYWORDS}

Elderly care / employment / full-time work / nurses' employment / part-time work / working hours

\section{Introduction}

ordic countries have higher employment rates for women than European countries (Drange \& Egeland, 2014; Haataja et al., 2011; Yerkes, 2013). At the same time, part-time work is common in most Nordic countries, especially among women. Norway has the largest proportion of women working part-time: $28 \%$ of all employed women worked part-time in 2015. The share was $26 \%$ in Denmark, 24\% in Iceland, $18 \%$ in Sweden, and $16 \%$ in Finland (OECD, 2017). This article explores nurses' working-hour practices through a career path. In this way, the article wishes to contribute to our knowledge about what regulates women's working-hour practice in a sector dominated by female employees.

Women's growing workforce participation and the struggle to balance work and family obligations can be influenced by the work-family policy of a welfare state (Morgan, 2013). Different types of welfare states regulate the sharing of responsibility between the family and the state (Crompton, 2006; Esping-Andersen, 2009; Saraceno \& Keck, 2011). Indirectly or directly, the context of the welfare state influences or frames

\footnotetext{
${ }^{1}$ You can find this text and its DOI at https://tidsskrift.dk/njwls/index

${ }^{2}$ Correspondence: kari.ingstad@nord.no Faculty of Nursing and Health Science, Nord University, Postbox 1490, N-8049 Bodø, Norway
} 
the possible choices for women employers. In Nordic countries, the state is known to facilitate women's active participation in working life (Bittman, 2004; Datta et al., 2008; Gregory \& Milner, 2009). In these countries, long parental leave schemes, good care schemes, and inexpensive and high-quality day-care centres are part of a welfare state system that makes combining a working career and having children easier (Rønsen \& Kitterød, 2010).

The share of full-time and part-time employment varies dramatically among branches and occupations, and a large proportion of part-time employees in Norway, as well as in most of Europe, work in the health and social services fields (Anxo et al., 2007). For instance, $43 \%$ of nurses in Norway work part-time, 34\% work long part-time, and 9\% work short part-time (less than 20 hours a week). Sixty-six percent of auxiliary nurses work part-time (Nergaard, 2016). Differences in part-time employment rates among sectors and occupations indicate that women's working-hour practices are a result of multiple reasons. Processes in the labor market, as well as in different work organizations, may impact women's working hours (Dick, 2010; Prowse \& Prowse, 2015).

However, the demand for labor in the health care sector is expected to increase considerably after 2020. Even without improvements in the standard of care, the need could double by 2060 (Holm et al., 2014). The connection between the shortage of personnel and part-time work is clear. Part-time professionals are potential full-time professionals and constitute a major labor resource, particularly in countries with a high proportion of part-time work (Abrahamsen et al., 2012; Virjo, 2006).

Maternal employment has been widely studied. However, there is a long-standing call for research that examines maternal employment with a longer-term perspective, especially given evidence of considerable instability in mothers' employment statuses following maternity (Hynes \& Clarkberg, 2005; Killewald \& Zhuo, 2015). Although women's career patterns clearly vary across time and among countries, less is known about what happens during career stages and why. Theoretical approaches examining labor market behavior from either a supply perspective or a demand perspective cannot capture the heterogeneity of women's participation in the labor market (Yerkes, 2010). This situation also emerges in the understanding of careers as linear life projects instead of an acknowledgment and focus on variations within the rhythms of life and work.

This study aimed to explore how working-hour practices are constructed over the careers of registered nurses. It focused on nurses because this is a typically female occupation in the Norwegian labor market (Kitterød et al., 2013; Statistics Norway, 2010). It is important to capture underlying forces influencing these women and their working-hour practices. By examining the experiences and reflections among women nurses who have been in the profession for most of their working lives, we can get insight about underlying forces and drivers for full-time or part-time employment. In this way, we can explore mechanisms and dynamics that have an impact on diversity in female employment. Furthermore, by acknowledging the diversity in women's employment across both time and generations (Yerkes, 2010), this analysis contributes to the understanding of how these patterns evolve. Thereby, this study seeks to promote a better understanding of the mechanisms that influence nurses' employment and how employment patterns can be changed. The main question asked and discussed is the following: How are working-hour practices constructed through careers of nurses?

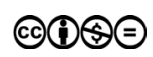




\section{Working Hours: Preferences and Constraints}

In developed countries, work-life balance has long been at the forefront of policy discourse (Abrahamsen et al., 2012; Craig \& Sawrikar, 2009; Gregory \& Milner, 2009). A key question in the work-life debate concerns the extent to which patterns reflect valueoriented choices or are a consequence of social and structural constraints. In previous literature, these assumptions are often seen as individualization theories vs. an institutional approach (Dahle, 2016; Gash, 2008; McRea, 2003; Mòsesdòttir \& Ellingsæter, 2017; Reed \& Blunsdon, 2006).

Hakim's preference theory is one of the individualization theories. Hakim (2000) argues that differences in women's employment status largely reflect differences in the relative value women place on involvement in work, family life, or other domains (Hakim, 2000; Reed \& Blunsdon, 2006). Hakim (2000) explains that women's working hours depend upon individual preferences and maintains that these preferences are relatively stable. She furthermore claims that women generally have less preference for paid work than men do (Hakim, 2000).

By contrast, other perspectives emphasize the extent to which various factors constrain women's choices. One set of constraints is referred to as structural (Crompton, 2006; Reed \& Blunsdon, 2006; Yerkes, 2010). The structure-oriented perspective claims that the differences concerning women's working hours are determined by the specific situation they are in. Women's ties to the labor market depend on the possibilities and limitations they encounter in working life and society in general (Crompton \& Lyonette, 2005; Lewis, 2009). This perspective points out the importance of alternative job opportunities, one's own (family) financial resources, and how easy it is to combine work and family on the organisation and institutional levels (Lewis, 2009; McRae, 2003). For example, lack of childcare and inconvenient school hours may limit maternal employment, especially full-time employment (Kangas \& Rostgaard, 2007; Yerkes, 2010). Cultural factors such as collective and social understandings about what the proper relationship between motherhood and paid work is, will also influence women's working-hours. From opportunities and constraints perspective, it means that an acceptable cultural view of working mothers can act as an opportunity, and a negative perception of working mothers can be understood as a constraint (Pfau-Effinger, 2004). Accordingly, the choices women make regarding the hours they work are not necessarily the results of personal preferences, but can as easily be based on the absence of alternative jobs that make it possible to combine work and family (Crompton, 2006; Mandel \& Semyonov, 2006; Yerkes, 2010).

Giddens' structuration theory (1984) bridges the preference and structural perspective and can be a relevant frame for analyzing the situation for female nurses in the Norwegian labor market. According to Giddens (1984), human beings and their actions cannot be studied separately from the social structure on which they codepend. Structures provide individuals with both opportunities and constraints. On the one hand, social structures constrain an individual's opportunity to act, while on the other hand, the same structures enable actors to competently participate in social life (Giddens, 1984).

At the same time, individuals can act in accordance with applicable structures, but they may also choose to act differently. The concept of structure in structuration theory is therefore productive and enabling, not primarily constraining (Giddens, 1984). For example, in Norway, it was a change in women's (and nurses') employment in the 1970s: 
women continued to work after having children. This created a demand for moderatelength leaves and publicly funded childcare, and as a result, the structures in society started to change; policies that kept women attached to the labor market were introduced (Dahle, 2016; Ingstad, 2016). When actors play their roles in various social systems, they participate in reproducing the roles as well as changing them. This dynamic of actions by members of a society is part of a continuous structuration process, which means that apparently locked structural patterns may be changed.

Thereby, in order to analyze nurses' working hour patterns, it is interesting to study nurses actions and reasoning for actions, as well as the structures surrounding these actions having an impact on nurses' full-time or part-time employment. This accordance with Giddens' structuration theory can be applicable for analysing how working-hour practices are construed throughout the professional careers of nurses working in nursing homes.

\section{The Norwegian Welfare State and Female Employment}

The structure of the Norwegian welfare state has in many respects made women's labor participation possible, but women's own work effort has in turn been a precondition of the development of the welfare state (Hernes, 2003). A higher labor supply means higher income from tax, which the Norwegian welfare state can utilize and offer public services that are more comprehensive. The women's employment rate is now nearly as high as the men's, as a result of historical development (Statistics Norway, 2012).

Welfare state provisions are also known to influence women's participation in the labor market (Budvig et al., 2016; Crompton, 2006; Esping-Andersen, 2009; Gash, 2008; Saraceno \& Keck, 2011). The typology for a social-democratic welfare regime (Esping-Andersen, 2009) is known to characterize the Norwegian welfare state. Such a welfare model is considered outstanding in its support for the employment of women, especially mothers (Boye \& Leira, 2012). Ideally, this welfare model aims to provide a decent standard of living for women on parental leave. However, the question arises whether this model is less beneficial for women who do not have full-time employment as they get a single-mother welfare benefit if they do not work. Empirical studies show that Norway usually has a higher proportion of single-mother households compared to countries that belong to the conservative regime model (Esping-Andersen, 2009; Korpi, 2000). Thereby, the structure of the Norwegian welfare state presumably gives Norwegian women gender equality in the labor market, as it is woman-friendly (Hernes, 2003). Nevertheless, the labor markets in Norway are characterized by surprisingly strong patterns of occupational gender segregation, both horizontally and vertically (Seierstad, 2011). The structure of the Norwegian welfare state can result in a gender-equality paradox with a high degree of gender equality for women as well as a gender-segregated labor market. Consequently, male and female employment dominates different sectors (Kjeldstad \& Nymoen, 2012). For example, only $10 \%$ of Norwegian nurses are men (Nergaard, 2016). The reason for such gender division is cultural according to Hauklien (2013). Cultural structures make it common for female employees to work part-time, and this type of employment is more common in the health care sector (Hauklien, 2013). Women in the health care sector also generally have lower wages than in male-dominated occupations (Statistics Norway, 
2012). Considering Norway's high female part-time work rate, part-time employment appears to be the norm for employment in certain sectors, such as the health care sector. This is a result of a historical development (Ingstad, 2016). Research shows that Norwegian nurses have significantly lower transition rates to full-time work and significantly higher transition rates to part-time work than most other occupations in Norway (Kitterød et al., 2013).

\section{Design and Method}

This study explores how working-hour practices are constructed over the careers of registered nurses. The intention is to get a deeper understanding of how working-hour practices occur and change. The study design is qualitative, and self-report data were collected, gathering retrospective data about events occurring in the past (Polit \& Beck, 2012), and how they affected the nurses' working-hour practices. The data for this study emerged from 22 in-depth interviews of registered nurses who have been in the profession for most of their working lives.

A semi-structured interview guide was used as the basis for the individual interviews that lasted from one to one-and-a-half hours. Interview questions concerned the respondents' careers, work lives, family situations, health statuses, and retirement plans. Since qualitative researchers continue to collect data until reaching a point of data saturation (Kvale, 2007), new information was no longer sought after 22 interviews.

A purposive sample was prepared in which all respondents were female nurses 56 years or older, who had mainly worked in nursing homes during their occupational careers. These nurses either were at the end of their working careers or had recently retired. Leaders in 13 different nursing homes were contacted to disseminate information to potential participants. After 1 week, the leaders of the nursing homes were contacted again, and they put us in contact with respondents. The nursing homes where the respondents worked or had been working were, as most nursing homes in Norway, nonprofit, owned, and operated by the municipality.

We selected nurses who could provide experience of lengthy careers, as they could best explain why nurses work part-time or full-time and why they reduced or increased their working hours over the course of their careers. Older nurses were able to provide vital information about how their profession had changed into a part-time occupation. The older nurses who had working-hour practices in nursing homes were recruited, as they could provide experience from the historical context of the labor market and society they were a part of.

\section{Analysis}

Throughout the process, interviews were recorded and transcribed and the findings were noted. Categorization of meaning was used as an analytical tool, meaning that the interviews were coded into categories (Polit $\&$ Beck, 2012). After careful reading of the data, underlying concepts and clusters of concepts were identified. During this analysis process, a category scheme was developed and data were coded according to the categories. No software was used during the coding. 
The respondents were from three counties, seven municipalities, 13 nursing homes, and 19 wards. This diversity was secured to ensure that the data captured as many variations in working conditions and organizations at different nursing homes as possible. It is possible that nurses from the same nursing home might have experienced their work situations differently, but the sample did not intend to fulfil a representative purpose. Instead, the sample sought to capture the range of experiences among nurses and to secure respondents with heterogeneous characteristics (Mason, 2005).

A professional translator translated the quotes cited in this article from Norwegian to English and the respondents were given fictitious names. The study was conducted based on the informed consent of the participants, who could withdraw from the study at any time. The study was not found reportable to the Norwegian Social Science Data Service (NSD). The study was conducted in adherence to the Helsinki Declaration of Research Principles (World Medical Association, 2013).

\section{Trustworthiness and Limitations}

The findings of the study should be interpreted with caution with regard to generalization. Nevertheless, the aim of qualitative research is not to extend findings derived from selected samples to the world at large, but rather to transform and apply them to similar situations in other contexts (Polit \& Beck, 2012). One strength of this study is its focus on nurses' self-reported experiences. We capture their attitudes, reflections, and explanations for their working-hour practice during a career path. This is done by thematic analysis from relatively extensive interviews. One limitation is that retrospective data are often less accurate than contemporaneous data (Polit \& Beck, 2012). Asking people why they reduced or increase their working hours in the past and the reason behind doing that may be a difficult question to answer. They may not remember clearly or try to present a rationale that was not there at the time, in order to present a favorable image of themselves. Nevertheless, retrospective data provide individuals the opportunity to reflect on their own choices and the outcomes of choices over a longer time span, not only the current situation.

The trustworthiness of the study is regarded as reasonable, as the analysis attempts to demonstrate a true picture of the nurses' experience and the research questions being presented. It is based on qualitative and substantial findings among a rather small sample of registered nurses in one sector of the Norwegian labor market.

\section{Findings}

Although nursing today typically promotes part-time work, there are variations across nurses' careers. This study has found that the careers of nurses generally follow one of four patterns:

- Part-time work throughout a career;

- Reduced working hours throughout a career;

- Increased working hours throughout a career; or

- Full-time work throughout a career.

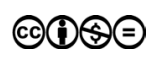




\section{Part-time Work Throughout a Career}

The nursing profession is typically a part-time occupation (Nergaard, 2016). Eight nurses among the 22 respondents had worked part time for the entirety of their working lives. One example was a nurse, aged 60 , who currently works $80 \%$ of full-time. She has worked in a number of institutions, and her hours have ranged from $50 \%$ to $80 \%$ :

I've worked shifts in various institutions-first in a half position, then I gradually increased. Now I'm in an $80 \%$ position. I've never worked a full-time position...I've seen that I can't manage to work a full-time position, so I never considered raising it to $100 \%$...I'm full of admiration for those who manage to work full-time positions in shifts and have a family in addition. That must be terribly difficult. (Anna)

Many of the participants who had worked part-time throughout their careers shared the experience of giving priority to their cohabitant's (i.e., men's) working careers. Because the women had worked part-time and assumed more of the responsibility for domestic work, their male partners could work more. The nurse quoted above also stated:

My husband works much and travels a lot in connection with his job. He always worked a lot...To keep the house in order and make things work, it was good to not have a full-time job. It has been necessary to keep the wheels turning at home... Most of what is inside the house—the cleaning, children, and laundry—have been my duties. (Anna)

A career pattern dominated by part-time work throughout the working career may be the result of a traditional work division in the family. In this investigation, nurses find it difficult to combine full-time work with home duties, and this leads many of them to work part-time. The fact that primarily women are the ones to work less when the children are young may be interpreted as reflecting the expectations our culture has for the woman as the caregiver (Pfau-Effinger, 2004). Even if the Norwegian welfare state facilitated mothers participating in the labor market for a long time (Hernes, 2003; Sejerstad, 2011), we see how nurses show an ambivalent attitude to full involvement in working life. We also see that nurses are captured by the gender-equality paradox of the Norwegian welfare state (Sejerstad, 2011) that provides labor market participation in a sector dominated by female part-time employment (Kitterød et al., 2013). While having a full-time job is not considered a problem for fathers, mothers may encounter negative attitudes if they spend much time working. Studies show, however, that the gender gap in housework is shrinking. This is the result of not only an increase in men's time but also a large decline in women's time spent on these activities (Bittman, 2004). This shows that the work division in the family is not constant but rather that it may vary over time and may also influence women's work hour practice during a career.

\section{Reduced Working Hours Throughout a Career}

Another pattern that emerged in this study depicts nurses working full-time, but then reducing their working hours over the course of their careers for a number of reasons. 
Four of the 22 nurses in this study describe this pattern. Although there were several reasons nurses reduced their working hours, the most important was that they had children. One nurse who had worked full time, but who chose to stay home after having children stated: 'I worked for two years after I completed my nursing training, and then I stayed home for 12 years. I stopped when we [my husband and I] had our third child' (Linda).

As described during interviews, respondents had children when the welfare schemes in Norway were not as beneficial as they are today. During this period, maternity leave lasted only 12 weeks-it was raised to 18 weeks after 1977 . The supply of slots in daycare centres was also far outstripped by the demand (NOU, 1996, p. 13). If parents wanted to work at all, short leaves and little possibility of obtaining a place in a day-care centre made alternative child care necessary. Upon having children, many parents were thus forced to curb their professional careers. One nurse stated:

There was no other way than staying at home. With three small children and no day-care centre...this was not what I wanted. I envied people who went to work and were able to move freely. I was forced to stay at home. I had no choice. Really, what would I have done with the children? (Michelle)

Traditional sociocultural expectations encourage women to remain at home (Pfau-Effinger, 2004). This subset of women workers may stem from systemic structural inequality. It is possible, for example, that women generally work more part-time hours so that they can stay home with small children because they earn less than men (Kangas \& Rostgaard, 2007). When the person earning the least works part-time, the family's financial loss is not as dramatic. One nurse stated:

We discussed it, my husband and I, about who actually should stay home. I would have, in fact, liked to work, but then there was the fact that one of us would have needed to take care of what was needed at home; otherwise, there would have been no time for our kids.

And he earned more than I did, so then it was natural that he worked. (Susanna)

Couples often divide the earning of income and household chores between them. While there is more social expectation and acceptance that women stay home with the children, men also often earn more than women. Occupations dominated by women often have lower incomes than those dominated by men (Bittman, 2004; Hauklien, 2013; Kitterød et al., 2013). Then, there is a financial advantage to having women work part-time and men work overtime. Part-time work is more common in typically female-dominated jobs such as nursing, whereas long hours are widespread in typical male jobs (Abrahamsen, 2002; Kjeldstad \& Nymoen, 2012). Hence, public-sector jobs are usually depicted as more flexible and family friendly than private-sector jobs (Ellingsæter, 1999; Halrynjo \& Lyng, 2009). This may be one explanation why it is most often women who are at home all the time or part-time, as they are employed in the family-friendly public sector, while men more often work full-time and work more in private-sector jobs.

Another set of salient reasons that can explain why nurses reduce their working hours involves health-related problems. A nurse working $75 \%$ of full-time hours after breaking her arm was bothered by arm pain and therefore reduced her work schedule: 
I have worked three-fourths of a full-time position most of the time, but after being on sick leave for a period of time, I knew I couldn't manage working so much. So I gave up a quarter of my job and now I work 50\%. (Cheryl)

Sickness absenteeism in the health and social services in Norway is far above the average for all other major industries. The rate in health and social services hovers around $9.6 \%$, compared with an average of $7.6 \%$ for all other occupational groups (Berge, 2010). Many employees in the health and social services sector suffer strain injuries, and many suffer from burnout. Health ailments can be an important reason why nurses reduce their work hours.

Since it is difficult to obtain full-time positions in many nursing homes in Norway, many nurses work part-time because they cannot obtain full-time positions. One nurse who previously worked full-time, but who, after moving, was forced to work part-time, stated:

We found that we needed to move to get closer to family and friends, but then I was unable to obtain a full-time position. I actually wanted a full-time position. This nursing home has two full-time positions; the rest are only part time...I really wanted to have a full-time position, but was forced to take the $75 \%$ position that was open. (Denise)

We can thus see how part-time work among nurses in Norway can depend on structural circumstances in the labor market. Given the organization of working hours, many nurses cannot hold full-time positions, even if they would prefer to do so. The lack of full-time positions, combined with well-entrenched work schemes that primarily facilitate part-time work, force nurses to work part-time. Studies in several countries show that many nurses are forced to work part-time because they are unable to obtain fulltime positions (Gash, 2008; McGregory, 2004).

\section{Increased Working Hours Throughout a Career}

Some nurses increase their working hours over the course of their careers. In our study, six of the 22 respondents had done so. Reportedly, one reason nurses in this study increased their working hours during their careers was that they had fewer care-giving duties as their children grew up. Two nurses who stayed home to mind their children for several years when they were young, but then increased their hours as their children grew, stated:

I stayed home for several years. When the children grew up, I started taking evening shifts because then my husband was home. (Siri)

When the children were old enough to cope alone, I started in regular shifts. Now I'm working full time and I have done so for about eight years. Before that, the size of my job varied, but it increased the more I could let the children take care of themselves. (June)

Here, it is clear that nurses' family situations and lack of alternative childcare contribute to constructing their careers. When children no longer need an adult's attention, parents 
have more freedom to increase their working hours. Other studies also show that balancing work and family is easier when children are older (Craig \& Sawrikar, 2009). The lack of childcare or lack of flexibility in opening hours or inconvenient school hours restricts the nurses' full-time employment, as the studies of Kangas and Rostgaard (2007) and Yerkes (2010) suggest.

Another salient point prompting nurses to increase their working hours is financial concerns. The need for one's own income may vary throughout a career. A new family situation prompted by divorce or any situation in which the spouse becomes unemployed or disabled impacts the financial situation for workers, including nurses, and the need for one's own income.

In this study, an older respondent who had divorced her husband after staying home for several years reported, 'I completed my training when I was 49. I trained late because I got divorced, and then I needed work-permanent employment and a full-time position' (Grethe). Another respondent who had stayed home for several years, but started working full-time after she was divorced said: 'Then I started working full time again. This had to do with my financial situation; I had to work full time then' (Lilly).

With these examples, it is clear that nurses' family and economic situations influence how they construct their careers. A new family situation after divorce or one in which the spouse becomes unemployed or disabled may affect the family's financial situation.

\section{Full-time Work Throughout a Career}

Although the nursing profession is both dominated by women and typically offers part-time hours, the present findings show that several nurses have worked full-time throughout their careers. Four of the 22 respondents exhibited this pattern. One who has worked full-time while raising two children said:

I have always worked full time... When I had completed my training, I started in the surgical ward. I was also the head nurse there for seven years. But then I didn't want to be a manager anymore... and there was a vacant position at the nursing home here, and when I applied, I got it. I have been here 13 or 14 years...I also worked in a full-time position when we had children...The maternal leave then was only two months. I feel it has gone well. I had a mother-in-law who helped us a lot with childrearing the first years. (Tina)

When asked what led her to always work full-time, this nurse continued:

I have enjoyed working. I wanted to work. Clearly the money has meant something; you have kids, build a house, and need to pay off the loan. But I haven't been forced to work full-time...No, it's instead because I've liked it. I have really enjoyed it, both at the hospital and here at the nursing home. (Tina)

Financial concerns may primarily justify nurses' working full-time positions, but job satisfaction is also an important reason for nurses' to work in full-time positions throughout their careers. In such a case, it is necessary that childcare is available. The respondents belong to a generation that gave birth to children when welfare schemes were not as comprehensive as they are today. Short maternity leaves and little chance 
of obtaining a place in a day-care center thus forced them, as parents, to find childcare alternatives. As a result, they often depended on nannies or grandparents who could watch their children while they were at work. This generation of women in Norway therefore worked full-time in spite of the lack of adequate welfare schemes that would enable them to combine employment with caregiving duties (Ellingsæter, 1999).

\section{Discussion and Conclusion}

In this article, we wanted to explore how different working-hour practices are constructed during careers, exemplified by a typical part-time and female profession: nursing.

The analysis suggests that we need to understand nurses' working-hour practices from a broad perspective of explanations. Working-hour pattern is a result of a dual process, where structures affect individual choices, and vice versa, as Giddens's structuration theory suggest (Giddens, 1984). The results show heterogeneity of working-hour practices, and that working hours may change during a career path.

Based on the stories told from the 22 nurses in this study, the working careers of nurses show four major working-hour patterns. One pattern describes nurses who work part-time throughout their careers. These women are family oriented, and tending to work part time exhibits a strategy for combining work and family care. It means they struggle to balance work and family obligations when they work in their occupations as nurses, despite the gender-friendly work-family policy of a welfare state (Morgan, 2013). Several studies show that women are more likely to assume care responsibilities and that employment patterns are highly gendered. Women are more likely than men to work part-time, even across a variety of age groups (Duncan, 2005; OECD, 2015; Statistics Norway, 2010; Yerkes, 2010).

The second pattern identified nurses who reduce their working hours as their careers progress. Some nurses follow this pattern due to health problems, others due to lack of childcare possibilities, or lack of full-time positions making full-time employment not an option. Other studies show that lack of available full-time positions in the Nordic labor market constrain women's possibilities for full-time work (Mòsesdòttir \& Ellingsæter, 2017; Nergaard, 2016; Nyberg, 2012). Although full-time hours are preferred, they are just not often available. There are considerable country variations in the fraction of involuntary part-time work, with the percentages being highest (about 30\%) in Finland and Iceland, lowest (about 20\%) in Denmark and Norway, with Sweden in between (Lanninger \& Sundström, 2014). Women's involuntary part-time work has been considered to be a problem, and is concentrated among less educated women and women employed in the health and service sectors (Drange \& Egeland, 2014; Lanninger \& Sundstrøm, 2014). The European Working Conditions Survey demonstrates an overall positive correlation at the country level between part-time and involuntary part-time working rates in Europe (Forssell \& Jonsson, 2005; Parent-Thirion et al., 2007). In groups where many work part-time, there is a lack of available full-time positions in the labor market (Nyberg, 2012). In the nursing field in Norway, part-time employment has been normalized and is considered natural. There are strong parttime norms and good part-time options (Kitterød et al., 2013). When conditions in the workplace are very conducive to part-time employment, it is possible that new nurses will be socialized into a part-time culture. Building a working culture where fulltime is 
"normalized" can therefore be important for meeting the need for labor in health care in the coming years.

Nurses who fit the third pattern increased their working hours throughout their careers. This shows that part-time work may be an effective short-term strategy for combining work and family care. Individual preferences for part-time working hours usually span a finite period ranging from 1 to 4 years, which reflects the need for reduced hours during particular life stages (Anxo et al., 2007; Yerkes, 2010). Some women are also forced to increase their working hours when they divorce, and must support themselves and their children.

Finally, the fourth pattern highlighted nurses who worked full-time throughout their careers. These nurses are career-oriented, like to work, and prefer working fulltime. Available full-time positions, adequate childcare, and job satisfaction are important reasons these women worked full-time throughout their careers.

The empirical analyses here demonstrate that nurses juggle working-hour practices with other decision-making, preferences, norms, and structural constraints. This means concrete circumstances and societal influences interact with the decision-making of nurses working part-time or full-time. Thus, what Giddens (1984) calls external contextual conditions influence the nurses' actions and responses regarding working full or part-time. Consequently, this study suggests that nurses do not choose their working hours in a vacuum, but that their working-hour practices are constructed via interactions with societal structures. Nurses' family situations, the job sector of the labor market, and the welfare state payment for family care and kindergarten affect the decisions and preferences of nurses during their occupational careers. The decisions nurses make about working part-time or full-time should be analyzed in relation to their jobs, and the job-sector they belong to, including how a welfare state structures options for female employment. Welfare programs such as childcare and parental leave make it possible for nurses to continue their careers after they have children. A lack of welfare schemes and full-time positions limits their career opportunities and forces nurses to work part-time.

Labor market opportunities and policy support of mothers' employment vary greatly between countries (Mòsesdòttir \& Ellingsæter, 2017). Nordic countries have opted for a model in which mothers are active in working life. By providing paid parental leave, day-care coverage, after school programs, and care for the elderly, the welfare schemes take over a larger proportion of traditional family caregiving responsibilities. In this sense, the social democratic welfare regime model supports a dual breadwinner model as well as the principle of individual financial autonomy for both genders (Esping-Andersen, 2009; Saraceno \& Keck, 2011). In current research, the extensive family policies of Scandinavian countries have been problematized and are described as hampering women's careers. Scandinavian family politics, especially for high-skilled women, is not beneficial. This is due to institutionalizing female work interruptions and strengthening occupational gender segregation (Grönlund et al., 2017). The part-time structure makes nurses vulnerable to the new governmental and economic order, New Public Management, introduced in the mid-1980s, which is now dominant. The new regime has proved to be best served with a high proportion of 'flexible' part-time workers (Dahle, 2016).

Recent studies show that many nurses want to work more, yet employers may be unable to offer full-time positions (Abrahamsen, 2010; Nergaard, 2016). As a result, 
involuntary part-time work is common among nurses in Norway. Studies also show that many part-time employees would prefer to work more if the working environment was good and the workload was adapted to their capacity (Moland, 2009). This indicates that part-time work in the health sector continues to answer to the needs of the employer, more than the needs and demands of female employees. Several studies show that part-time employees as a group give employers a labor reserve and reduce the costs of overtime work (Atkinson, 1984; Drange \& Egeland, 2014; Ede \& Rantakeisu, 2015; McGregory, 2004). This illustrates that there are important processes taking place in the sector of the working life where nurses work.

Another important factor is that the unions that organize nurses press for the abolishment of part-time hours and for the right to full-time positions-a stance that is also supported by some political parties in Norway. The premise of recreating nursing as a full-time profession, nurses waive accrued employee rights the people have struggled, as, for example, work every third weekend (Dahle, 2016; Ingstad, 2016), or accept timescheduling with elements of more unplanned working hours (Ede \& Rantakeisu, 2015). More work on weekends and unscheduled working hours, however, can collide with nurses' preferences for time off and for time with their families.

Applying Giddens's (1984) structuration theory to these nurses, they may act in accordance with the structures in place, but nurses may choose to act differently. Nurses' decisions may contribute to changing structural patterns that have apparently been well entrenched. The demands of nurses, trade unions, and politicians for full-time positions may thus contribute to changing the structures of working hours in the health services sector in Norway.

The working-hour patterns of nurses are thus neither predetermined, immutable nor determined strictly by one theoretical model. Nurses have different career patterns, and the working hours of individual nurses vary throughout their careers. Nurses' working-hour practices are shaped by opportunities and constraints, which again comprise structural, cultural, institutional, and individual-level dynamics.

This study contributes to our knowledge of how working-hour practices are constructed over the careers of nurses, a typical female and part-time occupation. As emphasized, nurses' decisions about full-time or part-time work are affected by surrounding factors, such as struggling with the work-family life balance, the working conditions in the health care sector, and economic status and situation. The findings of this study are based on analyzing data from Norwegian nurses more than 56 years of age when they were interviewed. The findings and analytical pattern could be different if younger nurses and nurses from other Nordic countries were interviewed. Other Nordic studies show that family income, social relations at the workplace, the possibility for flexible work arrangements, available full-time positions and job satisfaction all play important roles in women's employment (Nyberg, 2012; Sihto, 2015). This study confirms similar patterns. However, this study adds more knowledge about how women may decide differently over a carrier path, and about the reasons behind their decisions.

Even though part-time work in the Nordic countries seems to be normalized, we argue that working-hour patterns are constructed in an interaction with the structure of the welfare state, the labor market, and family-life practices. This implies that the working-hour practices for nurses can be changed from a typical part-time occupation into a full-time occupation. 


\section{References}

Abrahamsen, B. (2002). Heltid eller deltid? Kvinners arbeidstid i kvinnedominerte og mannsdominerte yrker [Full-time or part-time? Women's working hours in female dominated or male dominated occupations]. Report 2002:6. Oslo: Institute for Social Research.

Abrahamsen, B. (2010). Deltidsarbeid på retur? en sammenlikning av tre kull sykepleiere utdannet i 1977, 1992 og 2003. [Less part time work?: A comparison of nurses educated in 1977, 1992 and 2003]. Søkelys på arbeidslivet, 27(1/2), 15-18.

Abrahamsen, B., Holte, K. A., \& Laine, M. (2012). Work-family interference: Nurses in Norway and Finland. Professions \& Professionalism, 2(1), 60-74. doi: http://dx.doi. org/10.7577/pp.v2i1.19.

Anxo, D., Fagan, C. \& Smith, M. (2007). Part-time work in European companies: Establishment Survey on Working Time 2004-2005. Luxemburg: Office for Official Publications of the European Communities.

Atkinson, J. (1984). Manpower strategies for flexible organizations. Personnel Management, $16,28-31$.

Bittman, M. (2004). Parenthood without penalty: Time-use and public policy in Australia and Finland. In Folbre, N. \& Bittman, M. (Eds.) Family time: The social organization of care (pp. 224-237). London: Routledge.

Boye, T. \& Leira, A. (2012). Gender, Welfare State and the Market: Towards a New Division of Labour. London: Routledge Research in Gender and Society.

Budvig, M. J., Misra, J. \& Boeckmann, I. (2016). Work-family policy trade-offs for mothers? Unpacking the cross-national variation in motherhood earnings penalties. Work and Occupations, 43(2), 119-177. doi: https://dx.doi.org/10.1177/0730888415615385.

Craig, L. \& Sawrikar, P. (2009). Work and family: How does the (gender) balance change as children grow? Gender, Work \& Organization, 16(6), 684-709. doi: https://dx.doi. org/10.1111/j.1468-0432.2009.00481.x.

Crompton, R. (2006). Employment and the family. Cambridge: Cambridge University Press.

Crompton, R. \& Lyonette, C. (2005). The New Gender Essentialism - Domestic and Family Choices and Their Relation to Attitudes. British Journal of Sociology, 56(4), 601-20. doi: https://dx.doi.org/10.1111/j.1468-4446.2005.00085.x.

Datta, G. N., Smith, N. \& Verner, M. (2008). Perspective article: The impact of Nordic countries' family friendly policies on employment, wages, and children. Review of Economics of the Household, 6(1), 65-89. doi: https://dx.doi.org/10.1007/s11150-0079023-0.

Dahle, R. (2016). Heltidssykepleieren som forsvant [The full-time nurse who disappeared]. Tidsskrift for kjønnsforskning, 40(3-4), 168-185. doi: https://dx.doi.org/10.18261.

Dick, P. (2010). The transition to motherhood and part time working: Mutuality and incongruence in the psychological contracts existing between managers and employees. Work, Employment and Society, 24(3), 508-525. doi: https://dx.doi.org/ $10.1177 / 0950017010371648$.

Drange, I. \& Egeland, C. (2014). Part-Time Work in the Nordic Region II. A research review on important reasons. TemaNord 560. Denmark: Nordic Council of Ministers.

Duncan, S. (2005). Mothering, class and rationality. The Sociological Review, 53(1), 50-76. doi: https://dx.doi.org/10.1111/j.1467-954X.2005.00503.x.

Ede, L. \& Rantakeisu, U. (2015). Managing Organized Insecurity: The Consequences for Care Workers of Deregulated Working Conditions in Elderly Care. Nordic Journal of Working Life Studies, 5(2), 55-74. doi: http://dx.doi.org/10.19154/njwls.v5i2.4793.

Esping-Andersen, G. (2009). Incomplete revolution: Adapting welfare states to women's new roles. Cambridge, UK, Malden, MA: Polity. 
Ellingsæter A. L. (1999). Dual breadwinners between state and market. In Crompton, R. (ed.) Restructuring Gender Relations and Employment. The Decline of the Male Breadwinner (pp. 40-59). Oxford: Oxford University Press.

Forssell, J. \& Jonsson, I. (2005). Deltidsarbetslöshet och deltidsarbete $i$ Europa: Forklaringsmodeller och statistik [Unemployment and part-time work in Europe: Explaining models]. Stockholm: Arbetslivsinstitutet.

Gash, V. (2008). Preference or constraint? Part-time workers' transitions in Denmark, France and the United Kingdom. Work, Employment and Society, 22, 655-674. doi: http://dx. doi.org/10.1177/0950017008096741.

Giddens, A. (1984). The constitution of society: Outline of the theory of structuration. Cambridge: Polity Press.

Gregory, A. \& Milner, S. (2009). Work-life balance: A matter of choice? Gender, Work \& Organization, 16, 1-13. doi: https://doi.org/10.1111/j.1468-0432.2008.00429.x.

Grönlund, A., Haldèn, K. \& Magnusson, C. (2017). A Scandinavian success story? Women's labour market outcomes in Denmark, Finland, Norway and Sweden. Acta Sociologica, 60(2), 97-119. doi: https://doi.org/10.1177/0001699316660595.

Haataja, A., Kauhanen, M. \& Nätti, J. (2011). Underemployment and part-time work in the Nordic countries. Finland: Kela, Research Department.

Halrynjo, S. \& Lyng, S. (2009). Preferences, constraints or schemas of devotion? Exploring Norwegian mothers' withdrawal from high-commitment careers. British Journal of Sociology, 60(2), 321-343.

Hakim, C. (2000). Work-lifestyle choices in the 21 $1^{\text {st }}$ century: Preference theory. Oxford: Oxford University Press.

Hauklien, H. (2013). Omsorgsyrker, hierarki og kjønn; historiske linjer [Caring professions, hierarchy and gender; historical lines]. Norsk antropologisk tidsskrift, 24(3-4), 194-290.

Hernes, H. M. (2003). Welfare state and woman power: Essays in state feminism. Oslo: Universitetsforlaget.

Holm, E., Kjelvik, J. \& Strøm, B. (2014). Behovet for arbeidskraft i helse- og omsorgssektoren fremover. [The need for labor in the health care sector in the future]. Oslo: SSB 2014/14.

Hynes, K. \& Clarkberg, M. (2005). Women's Employment Patterns During Early Parenthood: A Group - Based Trajectory Analysis. Journal of Marriage and Family, 67(1), 222-239.

Ingstad, K. (2016). Turnus som fremmer heltidskultur [Shift schedules and full-time work]. Oslo: Gyldendal Akademisk.

Kangas, O. \& Rostgaard, T. (2007). Preferences or institutions: Work-family life opportunities in seven European countries. Journal of European Social Policy, 17(3), 240-256. doi: http://10.1177/0958928707078367.

Killewald, A. \& Zhuo, X. (2015). Mothers' Long-Term Employment Patterns. Upjohn Institute working paper, 15-247. doi: https://doi.org/10.17848/wp15-247.

Kitterød, R. H., Rønsen, M. \& Seierstad, A. (2013). Mobilizing female labour market reserves: What promotes women's transitions between part-time and full-time work? Acta Sociologica, 56(2), 155-171.

Kjeldstad, R. \& Nymoen, E. H. (2012). Part-time work, underemployment and gender: Worker versus job explanations. Oslo: Statistics Norway.

Korpi, W. (2000). Faces of inequality: Gender, class and patterns of inequalities in different types of welfare states. Social Politics, 7, 127-191. doi: https://doi.org/10.1093/sp/7.2.127.

Kvale, S. (2007). Doing interviews. London: Sage.

Lanninger, A. W. \& Sundström, M. (2014). Part-Time Work in the Nordic Region. TemaNord 503. Denmark: Nordic Council of Ministers. doi: http://dx.doi.org/10.6027/TN2014-503 Lewis, J. (2009). Work-family balance, gender and policy. Edward Elgar: Cheltenham. 
Mandel, H. \& Semyonov, M. (2006). A welfare state paradox: State interventions and women's employment opportunities in 22 countries. American Journal of Sociology, 111, 1910-1949. doi: http://dx.doi.org/10.1086/499912.

Mason, J. (2005). Qualitative researching. London, Thousand Oaks. New Delhi: Sage.

McGregory, R. C. (2004). Motivations for employing part-time nurses. A Dissertation Submitted in Partial Fulfillment of the Requirements for the Degree of Doctor of Philosophy in Economics. USA: The University of Wisconsin-Milwaukee.

McRae, S. (2003). Constraints and choices in mothers' employment careers: a consideration of Hakim's Preference Theory. British Journal of Sociology, 54(3), 317-338. doi: https:// dx.doi.org/10.1080/0007131032000111848.

Mòsesdòttir, L. \& Ellingsæter, A. L. (2017). Ideational struggles over women's part-time work in Norway: Destabilizing the gender contract. Economic and Industrial Democracy. doi: http://dx.doi.org/10.1177/0143831X16681483.

Moland, L. E. (2009). Deltid og sykefravcer i Skedsmo kommune [Part-time and sick leave in Skedsmo municipality]. Fafo-notat 2009:03. Oslo: Fafo.

Morgan, K. J. (2013). Path Shifting of the Welfare State Electoral Competition and the Expansion of Work-Family Policies in Western Europe. World Politics, 65(1), 73-115.

Nergaard, K. (2016). Utbredelsen av deltid og ulike arbeidstidsordninger [Part-time and different shift schedules]. In Ingstad, K. (Ed.) Turnus som fremmer heltidskultur [Shift and full-time work]. Oslo: Gyldendal Akademisk.

NOU 1996:13. (1996). Offentlige overføringer til barnefamilien [Child support systems]. Oslo: Barne-og familiedepartementet.

Nyberg, A. (2012). Gender Equality Policy in Sweden: 1970s-2010s. Nordic Journal of Working Life Studies, 2(4), 67-84. doi: http://dx.doi.org/10.19154/njwls.v2i4.2305.

OECD (2015). Education indicators in focus. Education and employment - what are the gender differences? OECD data. Available at: http://www.oecd-ilibrary.org/docserver/ download/5js4q17gg540.pdf? expires=1479973603\&id=id \&accname=guest \&checksum=DEF953848FF1CD23E4F9FACC13E706CB.

OECD (2017). OECD Labour Force Statistics 2016, OECD Publishing. doi: http://dx.doi. org/10.1787/oecd lfs-2016-en.

Parent-Thirion, A., Macías, E. F., Hurley, J. \& Vermeylen, G. (2007). Fourth European Working Conditions Survey. Dublin: European Foundation for the Improvement of Living and Working Conditions.

Pfau-Effinger, B. (2004). Development of Culture, Welfare States and Women's Employment in Europe. Ashgate: Aldershot.

Polit, D. F. \& Beck, C. T. (2012). Nursing research: Generating and assessing evidence for nursing practice, $9^{\text {th }}$ Edition. Philadelphia: Lippincott Williams \& Wilkins.

Prowse, J. \& Prowse, P. (2015). Flexible working and work-life balance: Midwives' experiences and views. Work, employment and society, 29(5), 757-774. doi: http://dx.doi. org/10.1177/0950017015570724.

Reed, K. \& Blunsdon, B. (2006). Should mothers work? An international comparison of the effect of religion on women's work and family roles. In Blyton, P., Blunsdon, B., Reed, K. \& Dastmalchian, A. (Eds.) Work-life integration: International perspectives on the balancing of multiple roles (pp. 135-149). New York: Palgrave Macmillan.

Rønsen, M. \& Kitterød, R. H. (2010). What makes full-time employed women satisfied with their working hours? Oslo: Statistics Norway.

Saraceno, C. \& Keck, W. (2011). Towards an integrated approach for the analysis of gender equity in policies supporting paid work and care responsibilities. Demographic Research, 25, 371-406. doi: http://dx.doi.org/10.4054/DemRes.2011.25.11. 
Seierstad, C. (2011). Exploring the Norwegian paradox of vertical sex segregation: Strategies and experiences in politics, academia and company boards. PhD thesis. Queen Mary: University of London.

Sihto, Tiina (2015). Choosing to Work? Mothers Return-to-Work Decisions, Social Class and the Local Labor Market. Nordic journal of working life studies, 5(3), 23-40. doi: http:// dx.doi.org/10.19154/njwls.v5i3.4805.

Statistics Norway (2010). Women and men in Norway. What the figures say. Revised edition 2010. Oslo: Statistics Norway. Available at: https://www.ssb.no/en/befolkning/artikler-og-publikasjoner/ attachment/39581? ts=132b433a8c8.

Statistics Norway (2012). Arbeid og lønnstatistikk [Work and salary statistics]. Available at: https://www.ssb.no/arbeid-og-lonn/statistikker/lonnansatt/aar/2013-03-20.

World Medical Association (2013). WMA Declaration of Helsinki: Ethical Principles for Medical Research Involving Human Subjects. Adopted by the $18^{\text {th }}$ WMA General Assembly, Helsinki, Finland, June 1964 and amended by the $64^{\text {th }}$ WMA General Assembly, Fortaleza, Brazil, October 2013.

Yerkes, M. (2010). Diversity in work: The heterogeneity of women's employment patterns. Gender, Work \& Organization, 17, 696-720. doi: https://dx.doi.org/10.1111/j.14680432.2009.00462.x.

Yerkes, M. (2013). Choice or constraint? Women's weekly working hours in comparative perspective. Sociologia, Problemas e Praticas, 72, 9-13. doi: http://dx.doi.org/10.7458/ SPP2013722616.

Virjo, I. (2006). Employment Rate Potential in the Nordic Countries: An overview. Copenhagen: Nordic Council of Ministers. 